\title{
PENGGUNAAN RETORT POUCH UNTUK PRODUK PANGAN SIAP SAJI
}

\author{
Murniyati ${ }^{*}$
}

\begin{abstract}
ABSTRAK
Retort pouch adalah kemasan fleksibel berbentuk pouch atau kantong yang digunakan untuk mengemas produk pangan siap santap (Meal Ready to Eat). Kemasan tersebut dibuat dari laminasi aluminium foil dan polimer, tahan terhadap proses sterilisasi. Pengemas retort pouch telah banyak digunakan pada produk sterilisasi ikan untuk menggantikan kaleng. Pengemas semacam kaleng harganya relatif mahal, sehingga menyebabkan harga produk yang dikemas dengan pengemas tersebut menjadi mahal. Dengan berkembangnya retort pouch processing, proses menjadi lebih efisien, produk bisa dipanaskan terlebih dahulu dengan memasukkan ke dalam air mendidih sebelum dikonsumsi. Retort pouch dengan bentuk yang tipis memungkinkan untuk mengurangi waktu pemanasan, dengan demikian dapat menghindari over cooking. Produk yang dihasilkan mempunyai warna yang lebih baik, tekstur kompak, dan tidak terjadi susut gizi. Produsen dapat mengurangi energi yang diperlukan untuk produksi retort pouch dibandingkan dengan kaleng. Selain beberapa keunggulannya, retort pouch juga memiliki kelemahan atau kendala. Kendala yang utama adalah modal yang besar untuk penyediaan mesin khusus dan proses pengisian yang lebih lambat dan kompleks dibandingkan dengan kaleng.
\end{abstract}

\section{ABSTRACT: The use of retort pouch for ready to eat products. By: Murniyati}

Retort pouch is a flexible package for ready to eat meals. It is made of aluminium foil and polymer that is resistant to sterilization processes. This pouch has been widely used for sterilized fish products to replace cans, therefore makes the products less expensive and more efficient. The thin profile of retort pouch permits a less heating time thus avoids over-cooking. Despite those benefits, the production of retort pouches requires costly special machines, not to mention that the packaging process is slower and more complicated than that of cans.

\section{KEYWORDS: $\quad$ retort pouch, flexible packaging, food product}

\section{PENDAHULUAN}

Proses pengawetan pangan dapat dilakukan dengan pengalengan, pendinginan, pembekuan, iradiasi, dehidrasi, freeze-drying, penggaraman, pengasaman, pasteurisasi, fermentasi, karbonasi, dan penambahan bahan pengawet (Sampurno, 2008). Pengalengan produk pangan merupakan salah satu metode pengawetan yang dilakukan menggunakan proses retort dengan tujuan untuk membunuh semua bakteri dalam pangan, termasuk yang terkandung dalam pengemasnya. Selanjutnya dikatakan, bahwa masalah utama pada proses pengalengan adalah proses pemanasan dengan suhu tinggi dan waktu yang lama. Biasanya proses tersebut akan mengubah rasa dan tekstur dari produk pangan, serta menurunkan nilai gizinya. Untuk mengatasi hal tersebut, waktu pemanasan harus dipersingkat dan suhunya juga perlu diturunkan dengan cara mengganti kaleng logam dengan wadah kemasan fleksibel yang lebih tipis. Wadah tersebut dinamakan retort pouch atau retortable packaging, untuk membedakannya dengan pengemas fleksibel biasa.

Dalam penggunaan istilah 'pengalengan' pengemas 'kaleng' adalah wadah yang terbuat dari logam, akan tetapi semua wadah lain yang bisa ditutup rapat juga dapat berfungsi sebagai kaleng. Contohnya adalah wadah kaca yang dapat ditutup rapat dan pengemas fleksibel yang terbuat dari polimer dan aluminium foil.

Harga pengemas semacam kaleng relatif mahal, sehingga menyebabkan harga produk yang dikemas dengan pengemas tersebut menjadi mahal. Dengan berkembangnya retort pouch processing maka 1) proses menjadi lebih efisien terutama berkenaan dengan penetrasi panas; 2) produk lebih praktis, bila memerlukan pemanasan sebelum dikonsumsi tinggal memasukkan di dalam air mendidih; dan 3) produk yang dihasilkan dapat dijual dengan harga yang lebih murah. Pengemas retort pouch telah banyak digunakan pada produk sterilisasi ikan untuk menggantikan kaleng, seperti yang dihasilkan oleh salah satu pabrik pengalengan ikan di Indonesia berupa tuna retort pouch dalam bentuk tuna flake in oil dan tuna flake in brine (Irianto, 2009).

Pengemas ini dinyatakan paling bermanfaat untuk makanan setelah pengemas kaleng, dan mempunyai potensi sebagai pengemas alternatif selain kaleng dan gelas (Anon., 2002; Mykytiuk, 2006). Selanjutnya

\footnotetext{
*) Peneliti pada Balai Besar Riset Pengolahan Produk dan Bioteknologi Kelautan dan Perikanan
} 
dikatakan bahwa tentara Amerika telah mempromosikan retort pouch ini pada waktu perang di tahun 1950-an. Idenya adalah selain produk menjadi lebih ringan, pengemas retort pouch dapat mempertahankan kestabilan produk makanan sebagaimana kaleng yang bobotnya lebih berat. Untuk ini, penelitian telah dilakukan sejak tahun 1960. Pada tahun 1965 di Italia pertama kali diproduksi pengemas fleksibel tahan panas. Di Jepang, teknologi retort pouch telah luas diterima dan digunakan dalam beberapa macam produk, mulai dari sukiyaki hingga sup.

Pada pengolahan daging kerang siap saji, untuk mempertahankan tekstur asli dan mutunya, produk tersebut dikemas vakum dalam retort pouch dan diproses dengan sterilisasi selama 35 menit. Produk ini dipak secara vakum dan dinilai baik oleh panelis penguji, rasa produk tetap dalam kondisi baik bahkan setelah penyimpanan selama 1 tahun pada suhu kamar (Bindu et al., 2004).

\section{DEFINISI DAN SPESIFIKASI RETORT POUCH}

Retort pouch adalah kemasan fleksibel berbentuk pouch atau kantong yang digunakan untuk mengemas pangan siap santap atau MRE (Meal Ready to Eat). Retort pouch dibuat dari laminasi aluminium foil dan polimer, tahan terhadap proses sterilisasi, dan seperti halnya kaleng logam, dapat disimpan selama bertahun-tahun pada suhu ruang (Sampurno, 2008). Sterilisasi adalah suatu kondisi yang diperoleh dari pengolahan pangan dengan menggunakan suhu tinggi dalam periode waktu tertentu sehingga tidak terdapat lagi mikroorganisme yang masih hidup (Hariyadi et al., 2000).

Semua bahan yang digunakan untuk pengemas retort pouch harus mempunyai titik leleh di atas suhu prosesnya. Demikian pula tinta dan perekat yang digunakan tidak boleh berubah warna dan berubah sifat pada suhu prosesnya. Mengingat hal tersebut, untuk lapisan sealant retort pouch tidak digunakan bahan polietilen (PE) karena titik leleh bahan ini di bawah $120^{\circ} \mathrm{C}$, namun digunakan polipropilen (PP) dengan titik leleh di atas $125^{\circ} \mathrm{C}$. Polipropilen tahan suhu tinggi sehingga dapat digunakan untuk sterilisasi pangan atau makanan panas, tahan asam sehingga bisa dipakai untuk sari buah dan tahan minyak sehingga bisa dipakai untuk produk olahan minyak (Syamsir, 2008b). Untuk mengantisipasi terjadinya pemanasan yang berlebihan dalam proses, dapat digunakan PP block copolymer dengan titik leleh lebih tinggi dari $135^{\circ} \mathrm{C}$ (Lampi, 1980).

Pilihan bahan baku untuk pembuatan retort pouch sangat penting antara lain harus melindungi bahan yang dikemas dari degradasi cahaya, perubahan kelembaban, masuknya mikroba, dan interaksi oksigen. Menurut Anon. (2007a), retort pouch adalah kantong dengan multi lapisan sebagai pengganti kaleng atau gelas untuk makanan dengan masa simpan yang lama. Terdapat sekitar 16 bahan dasar laminating dengan kombinasi yang berbeda sebanyak 100. Karakteristik yang penting untuk mendapatkan retort pouch yang baik adalah penyerapan gas (oksigen) rendah, penyerapan uap air rendah, sifat hidrofilik rendah, dapat disegel dengan panas dan tahan sterilisasi, bahan dapat dibentuk dengan tepat (bahan harus disetujui oleh Canadian Food Inspection Agency (CFIA), tahan terhadap lemak, minyak dan komponen makanan lainnya, mempunyai kekuatan fisik supaya tahan terhadap kerusakan fisik selama pengepakan, retorting, penyimpanan dan distribusi (robek, berlubang, dan terkikis), bahan untuk laminating harus tidak dapat berpengaruh terhadap makanan, dan dapat menghalangi cahaya (Anon., 2002).

Menurut Wibawa (2008), retort pouch dapat digolongkan ke dalam beberapa spesifikasi berdasarkan suhu dan waktu sterilisasi yaitu retort pouch yang dapat disterilisasi dengan suhu tinggi dan waktu yang singkat High Temperature Short Timel (HTST), suhu antara $120-35^{\circ} \mathrm{C}$, Ultra High Temperature (UHT), suhu antara $135-150^{\circ} \mathrm{C}$. Waktu sterilisasi untuk masing-masing suhu tersebut adalah sebagai berikut: di atas $120^{\circ} \mathrm{C}$, sekitar 30 menit, di atas 135 ${ }^{\circ} \mathrm{C}$, sekitar 10 menit, di atas $150^{\circ} \mathrm{C}$, sekitar $1-2$ menit.

\section{SEJARAH RETORT POUCH}

Dalam Perang Dunia II, Institut Fraunhofer di Muenchen, Jerman, menerima permintaan dari Angkatan Perang Jerman untuk mengembangkan suatu kemasan yang praktis untuk pangan yang enak, bergizi, dan siap makan. Pada saat itu, tentara Jerman mendapat jatah makanan berupa sosis yang diawetkan, roti kering, dan sayuran dikeringkan, yang dibentuk menjadi empat persegi dan dibungkus dalam aluminium foil atau cellophane (Sampurno, 2008). Selanjutnya dikatakan bahwa secara teknis penemuan ini bisa dipakai, tetapi pada prakteknya tidak berhasil diproduksi secara massal. Hal ini disebabkan karena investasi pada sistem kemasan kaleng sudah sedemikian besar sehingga tidak mungkin untuk menggantikan kaleng dengan retort pouch begitu saja. Pada tahun 1960-an Reynolds Metal Co mengembangkan retort pouch dengan spesifikasi: $\mathrm{PET} / \mathrm{Al}$ foil/CPP untuk mengemas kacang polong dan wortel, sauerkraut dan semur daging. Spesifikasi ini tidak banyak berubah sampai saat ini, dan perkembangan retort pouch dari segi komersial dari tahun 1960-an sampai sekarang juga tidak terlalu berarti. 
Kendala yang menghambat perkembangan retort pouch selama 50 tahun ini disebabkan karena perusahaan pangan sudah menginvestasikan uang yang sangat besar untuk pangan dalam kemasan kaleng logam, dengan kecepatan dan efisiensi sedemikian tinggi sehingga sukar untuk menggantikannya dengan mesin untuk pouch. Oleh karena itu, sampai saat ini mayoritas kemasan pangan retort masih berupa kaleng logam. Walaupun demikian ada satu segmen di sejumlah negara yang tetap menggunakan retort pouch selama ini, yaitu kalangan tentara.

Retort pouch sesungguhnya bukan barang baru di pasaran, dan dinyatakan bahwa hal ini merupakan perkembangan yang paling revolusioner pada pengemas setelah kaleng. Retort pouch, yang telah di pasarkan sejak tahun 1970-an, kemudian banyak digunakan oleh militer Amerika Serikat. Tanggal bersejarah bagi retort pouch adalah pada 15 Juni 2000 ketika StarKist, pabrik pengolah tuna yang dimiliki oleh Heinz (sekarang Delmonte) mengumumkan mulai menggunakan StarKist tuna dalam retort pouch (Anon., 2007b)

\section{BEBERAPA KEUNGGULAN RETORT POUCH DIBANDINGKAN DENGAN KALENG}

Retort pouch dengan bentuk yang tipis memungkinkan untuk mengurangi waktu pemanasan, dengan demikian dapat menghindari over cooking. Selain itu, produk yang dihasilkan mempunyai warna yang lebih baik, tekstur kompak, dan tidak terjadi susut gizi. Produsen dapat mengurangi energi yang diperlukan untuk produksi retort pouch dibandingkan dengan kaleng. Karena mempunyai lapisan yang tipis, pengemas retort pouch akan lebih cepat dalam memindahkan panas menuju critical point. Selama proses, retort pouch akan mempercepat penetrasi panas yang dibutuhan untuk sterilisasi dengan minimal over cooking dari produk. Oleh karena itu, untuk produk makanan yang mengalami susut selama proses panas, retort pouch sangat bermanfaat dalam meningkatkan mutu, karena terdapat beberapa zat gizi yang sensitif terhadap panas. Dengan retort pouch, waktu memasak menjadi lebih pendek sekitar $50 \%$ dibandingkan dengan kaleng dan membuat tekstur pangan terasa lebih alami serta nilai gizinya lebih baik (William, 2007).

Retort pouch lebih mudah dalam distribusi sehingga menurunkan biaya transportasi serta tidak memerlukan ruangan yang besar untuk menyimpan suku cadang maupun sampahnya. Karavan dengan ukuran $45 \mathrm{ft}$ dapat memuat 200.000 kaleng ukuran 8 oz atau 2,3 juta retort pouch. Retort pouch lebih tipis sehingga lebih mudah dibawa, lebih ringan sehingga menghemat tenaga dan lebih cepat dalam proses pemanasan atau sterilisasi. Dengan waktu pemasakan yang lebih pendek, rasa dari produk menjadi lebih enak terutama untuk makanan yang lunak. Penampakan dari retort pouch lebih menarik dan hal ini akan menaikkan nilai jual dari produk yang dikemas (Peters, 2001). Produk pangan yang dikemas dalam retort pouch mempunyai ketahanan yang tinggi selama penyimpanan, distribusi, dan pemajangan yang normal (Anon., 2001). Selanjutnya dikatakan bahwa pengemas tidak bereaksi dengan senyawa-senyawa yang terdapat pada bahan pangan, pengawetan bahan pangan dengan sterilisasi menjadi jauh lebih mudah, cepat, ringan, dan mudah dibuka (hanya disobek).

\section{KELEMAHAN DARI RETORT POUCH}

Selain beberapa keunggulan dari retort pouch, juga terdapat kelemahan atau kendala. Kendala yang pertama adalah modal yang besar untuk penyediaan mesin khusus. Pengisian lebih lambat dan komplek dibandingkan kaleng, demikian juga proses panas (uap/udara, uap tetap, dan lain-lain). Proses panas merupakan proses yang cukup rumit karena beberapa parameter selama pengolahan harus diamati (sisa udara dan ketebalan kemasan). Pengemas retort pouch sangat mudah tertusuk maka memerlukan pembungkus tambahan untuk distribusinya. Peralatan khusus seperti burst tester, diperlukan untuk test kebocoran pengemas (Anon., 2002).

Retort pouch dapat dibentuk terlebih dahulu dalam tiga sudut pengemas yang diseal atau bentuk memanjang dengan pengisian dan seal dikombinasi pada kemasan. Ada beberapa sistem komersil untuk pengisian dan penyegelan yang biasa digunakan. Salah satunya adalah kemasan yang dibentuk melalui gulungan dengan seal dikedua tempat bersama-sama. Bahan yang berbentuk pipa secara otomatis dipotong memanjang dan bagian bawah diseal sebelum pengisian.

Selain sifat termal di atas, sifat mekanik juga memegang peranan yang sangat penting. Untuk proses yang tidak terlalu lama dan suhu di bawah $125^{\circ} \mathrm{C}$, cukup menggunakan bahan dua lapis saja yaitu Nilon 15 mikron/tinta/adhesive/CPP 60-100 mikron. Jika proses lebih lama dan lebih panas, pengemas di atas dapat memuai di atas elongation point-nya dan pengemas akan pecah. Nilon digunakan karena sifat elongasinya yang tinggi. Untuk proses di atas $125^{\circ} \mathrm{C}$ dengan waktu di atas 20 menit, perlu digunakan aluminium foil 7-12 mikron sehingga pengemas lebih kokoh dan dapat menahan pemuaian yang berlebihan. Struktur lengkapnya adalah PET 
(Poly EthyleneTerephtalate) 12 mikron/tinta/adh/AI 712 mikron/adh/CPP (Casted Poly Propylene) 70-100 mikron. Jika suhu prosesnya lebih tinggi dan waktunya lebih lama lagi maka perlu ditambahkan bahan nilon 15 mikron di tengahnya supaya tensile strength-nya meningkat. Struktur lengkapnya adalah PET 12 mikron /tinta/adh/NY (Nilon) 15 mikron /AI 712 mikron /adh $^{* *} /$ CPP $70-100$ mikron (Sampurno, 2008).

\section{PERBEDAAN PROSES STERILISASI PADA KALENG DENGAN RETORT POUCH}

Proses sterilisasi dilakukan pada suhu di atas $250^{\circ} \mathrm{F}\left(121^{\circ} \mathrm{C}\right)$, baik untuk kaleng maupun retort pouch. Alat yang digunakan untuk keperluan ini dinamakan retort chamber atau autoclave. Selama proses retort, terjadi pemanasan pada bahan pangan, termasuk pengemasnya. Semua benda akan memuai bila dipanaskan, termasuk retort pouch dan kaleng serta makanan, kuah dan udara (head space) di dalamnya. Untuk mengimbangi pemuaian ini, diperlukan tekanan dari luar wadah supaya wadah tersebut tidak meledak. Tekanan ini dinamakan external pressure, dan dengan adanya external pressure ini, walaupun wadah tetap memuai di dalam autoclave namun pemuaian ini masih di bawah elongation point-nya, sehingga setelah proses pendinginan wadah akan kembali ke bentuk aslinya lagi. Karena kaleng secara fisik lebih kaku dan kokoh, sehingga external pressure yang diperlukan hanya sekitar $205 \mathrm{kPa}$, sedangkan untuk retort pouch perlu external pressure sekitar 274-308 kPa untuk mencegah pouch pecah atau seal terbuka. Oleh karena itu, autoclave yang biasanya digunakan untuk proses retort kaleng belum tentu dapat digunakan untuk proses retort pouch.

\section{PRODUK YANG COCOK UNTUK RETORT POUCH}

Dengan berbagai kelebihannya, retort pouch juga punya beberapa keterbatasan. Keterbatasan pertama adalah daya tahannya terhadap perlakuan panas yang terlalu lama. Jika retort pouch dipanaskan dalam suhu lebih dari $130^{\circ} \mathrm{C}$ selama lebih dari 45 menit maka laminasinya akan lepas sehingga kemasan menjadi keriput bahkan lapisannya terkelupas. Oleh karena itu, untuk memproduksi retort pouch untuk ikan sardin atau mackerel sampai durinya lunak, diperlukan dua kali proses, yaitu proses pertama (pre cooking) dilakukan pemasakan ikan di luar kemasan sampai durinya setengah lunak, kemudian dilakukan pemasakan tahap kedua dengan pemasakan ikan di dalam pengemas dengan waktu di bawah 30 menit. Jika menggunakan kaleng, setelah proses pre cooking ikan dapat dimasak sampai durinya lunak langsung di dalam kaleng dengan waktu lebih dari 45 menit, jika perlu. Selain keterbatasan daya tahan terhadap panas, ukuran kantong yang tipis juga dapat menjadi kendala jika produk yang ingin dipasarkan mempunyai bentuk yang besar dan tebal, misalnya (sup) buntut, iga, belado telur, dan sebagainya.

Seperti halnya kaleng, masa simpan produk dalam retort pouch dipengaruhi suhu penyimpanannya. Di daerah beriklim panas (di atas $40^{\circ} \mathrm{C}$ ) masa simpan

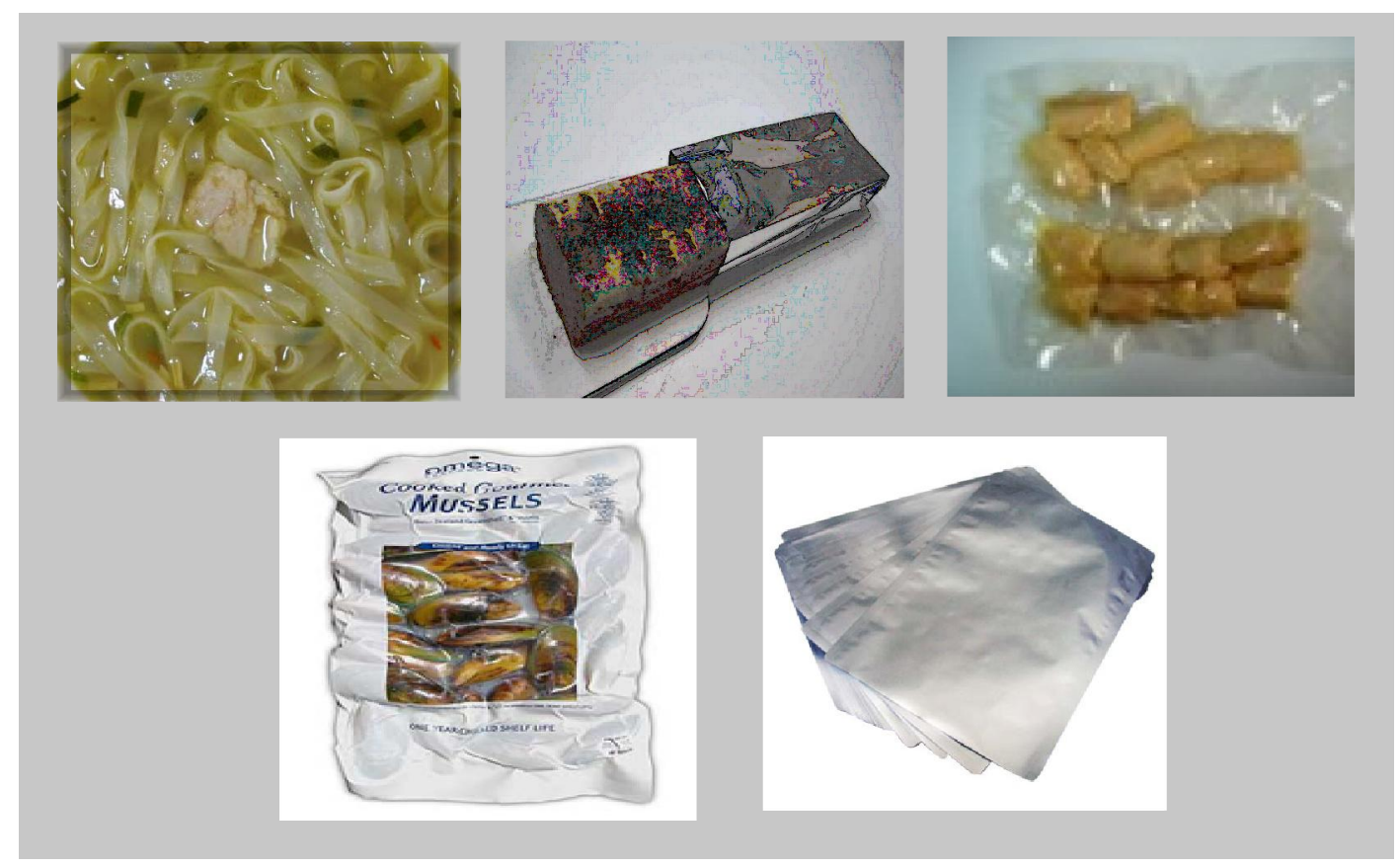

Gambar 1. Pengemas retort pouch untuk berbagai produk (Anon., 2003). 
produk adalah 6 bulan, pada suhu ruang $\left(25-30^{\circ} \mathrm{C}\right)$ selama 3 tahun, dan di almari pendingin selama 5 tahun.

Pada pengemasan sup sirip hiu digunakan pengemas hermetis (kedap) untuk mencegah terjadinya kontaminasi mikroba ke dalam produk selama penyimpanan. Pengemasan dilakukan sebelum produk disterilisasi dan jenis kemasan yang digunakan bervariasi, tetapi dipilih pengemas retort pouch. Alasan pemilihan pengemas jenis ini adalah karena bobot pengemas lebih ringan dan bentuk lebih menarik sehingga sesuai untuk konsumen kelas menengah ke atas (Syamsir, 2008a). Menurut Martin (2006), suatu perusahaan pengemas telah memproduksi pengemas retort pouch bagi ragi cair untuk pembuatan bir yang dapat mencegah oksigen dan sinar ultra violet.

\section{PENGGUNAAN RETORT POUCHDI INDONESIA}

Penggunaan retort pouch untuk produk makanan di Indonesia sudah banyak dilakukan, terutama adalah produk-produk perikanan seperti tuna, sardin atau cumi. Tuna retort pouch adalah makanan sehat terbuat dari ikan tuna, dikemas dalam retort pouch, sangat lezat, sehat, dan bergizi (Anon., 2009a). Selanjutnya dijelaskan dalam Anon. (2009b) bahwa Tuna retort pouch yang diproduksi oleh pabrik pengalengan ikan di Indonesia dibuat dari ikan tuna yang berasal dari perairan Indonesia dan perairan lainnya. Ikan tuna tersebut dikemas dalam retort pouch ukuran kecil untuk konsumen tertentu. Kemasan bervariasi dengan ukuran antara 300 gram sampai dengán 3 kilogram. Tuna retort pouch yang dihasilkan telah melalui proses dengan pengawasan mutu yang sangat ketat. Beberapa produk perikanan yang dikemas dalam retort pouch biasanya ditujukan untuk konsumen di luar negeri sesuai permintaan. Sebagai contoh, untuk permintaan konsumen di Jepang telah diproduksi Sea Chicken Flakes 500 g, Tuna Flakes in Oil 3 kg, Sea Chicken Beihanyou 3 kg, Sea Chiken Mild Flakes $3 \mathrm{~kg}$, dan Tuna Flakes in Brine $3 \mathrm{~kg}$ (Anon., 2009b). Untuk produk lain seperti bakso (ikan, cumi), sayuran yang dicampur ikan, nasi dengan ikan atau ayam, diproduksi dengan nama Minit Rice With Sardine Tomato Sauce $300 \mathrm{~g}$, Minit Rice With Curry Fish 300 g, Minit Rlce With Curry Vegetable $300 \mathrm{~g}$, Minit Rice With Curry Chicken 300 g, Minit Rice With Curry Fish 300 g, Sotong Balls $500 \mathrm{~g}$, Curry Puff Sardine $400 \mathrm{~g}$. Sedangkan untuk produk selain perikanan diproduksi pula seperti Green Peas $250 \mathrm{~g}$, Beef Balls $500 \mathrm{~g}$, dan Curry Puff (Potatoes, Beef, Chicken) $400 \mathrm{~g}$.

\section{PENUTUP}

Proses pemanasan suhu tinggi dan waktu yang lama pada proses pengalengan biasanya akan mengubah rasa, tekstur, dan menurunkan gizi dari produk pangan tersebut. Untuk mengatasi hal tersebut waktu pemanasan harus dipersingkat dan suhunya juga perlu diturunkan dengan cara mengganti kaleng logam dengan wadah kemasan fleksibel yang lebih tipis. Wadah tersebut adalah retort pouch atau retortable packaging, untuk membedakannya dengan kemasan fleksibel biasa. Retort pouch mempunyai beberapa kelebihan dan keuntungan dibandingkan dengan kaleng tetapi juga mempunyai beberapa kelemahan terutama karena harus menggunakan peralatan khusus yang cukup mahal.

\section{DAFTAR PUSTAKA}

Anonim. 2001. Teknologi Tepat Guna Untuk Agroindustri Kecil Sumatera Barat. Dewan Ilmu Pengetahuan, Teknologi dan Industri Sumatera Barat.

Anonymous. 2002. Flexible retort pouch defects. Identification and classification. Canadian Food Inspection Agency. http://www.inspection.gc.ca/english/ fssa/ fispoi/man/pousac/chap2e.pdf. Accessed June 20, 2009.

Anonymous. 2003. Extended shelflife with retort pouches. ttp://www.retortpouches.com/. Accessed May 20, 2009.

Anonymous. 2007a. Journal of Food Process Engineering. Volume 4 Issue 1.Published Online: 30 Jan 2007.@ 2009 Wiley Periodicals, Inc. p. 1-18.

Anonymous. 2007b. Retort Pouch - A Fast-Growing Packaging Technology in Today's Consumer World. FLEXNEWS. 28/11/2007. http://www.flex-news-food. com/ pages. Accessed June 05, 2009.

Anonymous. 2009a. Tuna Retort Pouch. http:// www.tunaindonesia.com/products. Accessed October 22, 2009.

Anonymous. 2009b. Seafood/ Processed Meats. http:// www.rexindustry.com/ default.asp. http:// www.tunaindonesia.com/products. Accessed October 22, 2009.

Bindu, J., Srinivasa, G.T.K., Unnikrishnan, N.T.S. 2004. Ready-to-eat mussel meat processed in retort pouches for the retail and export market. Packaging Technology and Science. Volume 17, Number 3, May 2004 , pp. 113-117(5). John Wiley \& Sons, Ltd.

Hariyadi, P., F. Kusnandar, dan N. Wulandari. 2000. Penanganan Kemasan Dalam Proses Termal. Pusat Studi Pangan dan Gizi IPB, Bogor.

Irianto, H.E. 2009. Pengembangan Produk Pangan dan Perannya dalam Pembangunan Nasional. Orasi Pengukuhan Guru Besar Bidang Teknologi Pangan 14 Juli 2009. Fakultas Teknologi Industri Pertanian. Universitas Sahid Jakarta. 
Lampi, R.A. 1980. Retort Pouch: The Development of Basic Packaging Concept in Today's High Technology Era. U.S. Army Natick Research and Development Laboratories. Food \& Nutrition Press, Inc.

Martin, Kathryn. 2006. Retort pouches prove multifunctional. Food Packaging Materials \& Containers. http://www.highbeam.com/doc/1G1-153240760.html. Accessed May 10, 2009.

Mykytiuk, A. 2006. Retort Flexible Packaging. The Revolution Has Begun. http://www. idspackaging.com/ Common/exhib_11961/Case_File_26.pdf. Accessed July 12, 2009 .

Peters, James. W. 2001. Convenience may speed retort pouch acceptance: consumer-friendly zippers are imminent. Food \& Drug Packaging. Publ. Dec. 1
Sampurno, B. 2008. Retortable Packaging http:// www.foodreview.biz/preview.php?view \&id=55692. Accessed July 06, 2009.

Syamsir, E. 2008a. Pengembangan Produk: Shark Fin Soup. 04http://ilmupangan. blogspot.com/2008/03/ pengembangan-produk-shark-fin-soup. Accessed May 19, 2009.

Syamsir, E. 2008b. Bahaya dan Keuntungan Kemasan Primer. Tabloid Peluang Usaha, No 24 Thn III, 11-24 Agustus 2008.

Wibawa, H. 2008. The Basic of Retort Pouch. Flexible Packaging. $h t t p: / / i d$. wordpress.com/tag/flexible-packaging. Accessed June 13, 2009.

Williams, T. Scott. 2007. Pouch Processing. (http:// www.retorts.com/white-papers/pouch-processing/. Accessed 2009 July 03. 